suggest that in this patient who was not thrombocytopenic, the hypothalamic lesion was a deposit. In previously reported cases, diabetes insipidus has been described as a presenting symptom (Joseph and Levin, 1956) and also has occurred during the course of the disease (Laakso, 1964). Most cases have been adults who have all had acute leukaemia and there are a few reports of children having diabetes insipidus as a complication of acute lymphoblastic (Malter $e t$ al., 1969) or acute myeloblastic leukaemia (Joseph and Levin, 1956).

No cases found in the literature had a markedly raised $\mathrm{Hb} \mathrm{F}$ and it seems likely from our studies that this was a consequence of his leukaemia.

\section{References}

Camarri, E. \& Fanteria, E. (1972) Diabetes insipida en el curso de una leucemia aguda. Interpretacion patogenetica. Sangre (Barc), 17, 3, 401.

Castaigne, P. \& Hubault, A. (1953) Diabète Insipide et leucémic. Revue du Practicien, 3, 1871.

EILERSEN, P. (1960) Diabetes insipidus presenting as leukosis. Ugeskrift for Laeger, 122, 1249.

Fabiani, F. \& LuCENTINi, L. (1955) Case of acute hemocytoblastic leukaemia beginning and ending with the complicating disease of diabetes insipidus. Progressive Medicine, 11, 269.
FlynN, J.E. \& Bowers, J.M. (1947) Acute lymphatic leukaemia with diabetes insipidus and uraemia. Journal of Urology, 58, 106.

Hall, R., Ormston, B.J., Besser, G.M., Cryer, R.J. \& McKENDRICK, M. (1972) The thyrotrophin releasing hormone test in diseases of the pituitary and hypothalmus. Lancet, i, 759.

JoSEPH, M.C. \& LEvin, S.E. (1956) Leukaemia and diabetes insipidus: case report with unexpected effect of cortisone. British Medical Journal, 1, 1328.

LAakso, W.B. (1964) Diabetes insipidus secondary to acute leukaemia: a case report. American Journal of Medical Science, 247, 451.

Malter, I.J., Gross, S. \& Teree, T.M. (1969) Diabetes insi pidus complicating acute lymphocytic leukaemia. American Journal of Diseases of Children, 117, 228.

Miller, V.I. \& Campbell, W.G. (1971) Diabetes insipidus as a complication of leukaemia. Cancer, 28, 666.

Rosenzweig, M.D. \& Kendall, J.M. (1966) Diabetes insipidus as a complication of acute leukaemia. Archives of Internal Medicine, 117, 397.

SPIERS, A.S.D. (1972) Chemotherapy of acute leukaemia. Clinics in Haematology, 1, 127.

Tattersall, M.H.N., SPiers, A.S.D. \& Darrell, J.H. (1972) Initial therapy with combination of five antibiotics in febrile patients with leukaemia and neutropenia. Lancet, i, 162.

White, J.M. (1972) In: Haematology (Ed. by A. V. Hoffbrand and S. M. Lewis), p. 214.

\title{
Megaloblastic anaemia associated with the oral contraceptive pill
}

\author{
Michael M. Meguid \\ M.B., B.S.
}

\author{
WALTER Y. LOEBL \\ M.R.C.P.
}

Bethnal Green Hospital, London, E.C.3

\begin{abstract}
Summary
A 27-year-old housewife suffered from severe headaches for a period of 2 years which developed after she started taking an oral contraceptive pill. During this time she gradually developed folic acid deficiency anaemia. This resulted from the inhibition by 'the pill' of the intestinal conjugase system required to deconjugate polyglutamic folate. The patient's headache did not recur after stopping the pill and her anaemia improved with folic acid supplement. The relation between folic acid metabolism and 'the pill' is discussed.
\end{abstract}

Correspondence: Dr M. M. Meguid, Department of Surgery, Harvard Medical School at Peter Bent Brigham Hospital, Boston, Massachusetts 02115, U.S.A.
Megaloblastic anaemia associated with oral contraception

A large number of metabolic side effects induced by the contraceptive pill have been described (Drill, 1965). Shojania, Hornady and Barnes (1968), Snyder and Necheles (1969) and Streiff (1970) have described lowered levels of serum folate in women on oral contraceptives, but overt megaloblastic anaemia appears to be uncommon. The following report describes this entirely remediable condition which presented in an insidious form.

\section{Case report}

Mrs M.K., aged 27 years, was seen in the casualty department. She had taken 16 tablets of codeine 


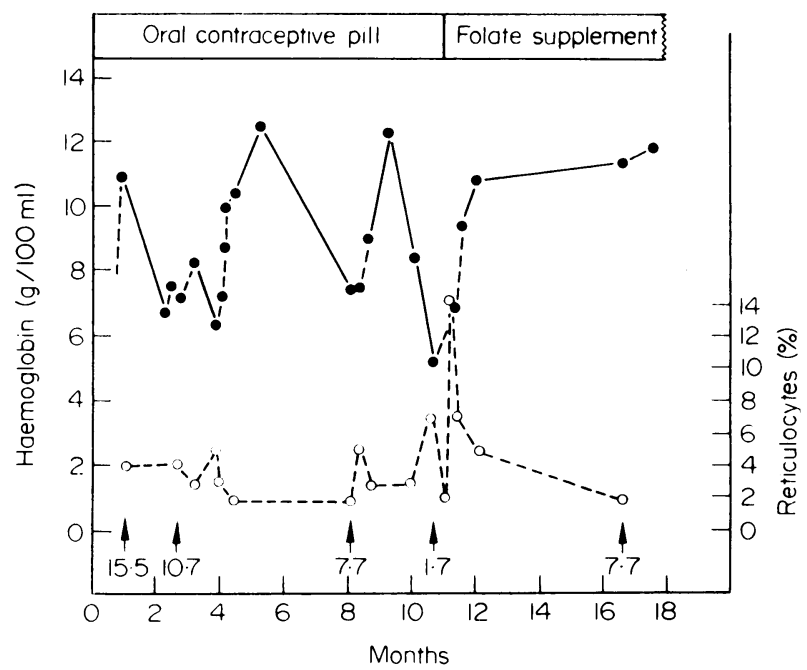

FIc. 1. The course of haematological changes and their relation to medication. $\odot$, reticulocytes; $\odot$, haemoglobin; -.$\uparrow$, serum folate $(\mathrm{ng} / \mathrm{ml})$.

compound over the previous $6 \mathrm{hr}$ for a severe headache. For the past 2 years she had recurrent severe diffuse headaches which had been attributed to tension caused by her domestic problems. Her past medical history was non-contributory. She had two children aged 5 and 2 years and following the birth of her second child she was prescribed a contraceptive pill containing $2.5 \mathrm{mg}$ Lynoestrenol and $75 \mu \mathrm{g} /$ Mestranol.

On admission she complained of dizziness and tinnitus. She was drowsy, tachypnoeic, lean and pale. There were no palpable lymph glands, and the remainder of the physical examination was normal. She was admitted for observation and her symptoms subsided over a 24 -hr period.

Investigations confirmed anaemia. The haemoglobin was $7.9 \mathrm{~g} / 100 \mathrm{ml}$, the PCV $27 \%$, the MCHC $29.5 \%$, the reticulocyte count was $4 \%$. The blood film showed moderate anisocytosis with some hypochromia. The platelets appeared normal. The sedimentation rate was $5 \mathrm{~mm} / \mathrm{hr}$ (Westergren). The direct Coombs test was negative. The serum iron was 143 $\mu \mathrm{g} / 100 \mathrm{ml}$, total iron binding capacity $380 \mu \mathrm{g} / \mathrm{ml}$. The serum Vitamin $B_{12}$ was $150 \mathrm{pg} / \mathrm{ml}$, the serum folate was $15.5 \mathrm{ng} / \mathrm{ml}$, but gradually fell to $1.7 \mathrm{ng} / \mathrm{ml}$ over the next 10 months.

She was discharged after $48 \mathrm{hr}$ and outpatient follow-up was arranged. During the following 11 months the patient was readmitted three times for recurrent anaemia (Fig. 1). Repeated investigations which gave normal results included the following: urinalysis, blood urea and electrolytes, serum proteins and immuno-electrophoresis, direct Coombs test, blood LE cells, anti-nuclear factor, Wassermann reaction and gastric and thyroid antibodies.
Chest X-ray, barium meal and follow-through revealed no abnormalities. The red blood cell osmotic fragility and glucose-6-phosphate dehydrogenase were also normal, as were Ham's test for paroxysmal nocturnal haemoglobinuria, haemoglobin electrophoresis, serum calcium and phosphate, alkaline phosphatase, bilirubin and liver function tests, faecal fat and a pentagastrin gastric secretion test. Tests for occult blood and a Schilling test were negative.

During her first outpatient visit a bone marrow aspiration was done. Erythropoiesis was markedly increased and, although the red cell series was mainly normoblastic, a few megaloblasts were noted. Stainable iron was markedly increased. The differential diagnosis was thought to be either idiopathic or drug induced haemolytic anaemia. She was therefore instructed to stop all medication, but she continued taking the pill unknown to us. The anaemia persisted and a second bone marrow aspiration, 6 months later, showed that the marked erythroid hyperplasia was now predominantly megaloblastic. Serum folate at the time was lower but still within normal limits. Each hospital admission appeared to cause a remission in the anaemia, but these remissions were not sustained. On the last admission the serum folate level was abnormally low and a further bone marrow aspiration showed grossly megaloblastic erythropoiesis. It was now discovered that she had continued to take the contraceptive pill, and a careful dietary history established that her estimated intake of folate was also well below normal, at $9 \mu \mathrm{g} /$ day. The pill was stopped and she was started on an oral folate supplement of $5 \mathrm{mg}$ daily. Four days later the reticulocyte count was $14.4 \%$ and the haemoglobin 
remained at normal levels thereafter. Her headaches did not recur after stopping the pill.

\section{Discussion}

The daily requirement of folate is said to be between $50 \mu \mathrm{g}$ (Herbert, 1962) and over $100 \mu \mathrm{g}$ (Perry and Chanarin, 1968). In normal mixed diets $75 \%$ of folate is in the polyglutamate form, having a chain of seven glutamic acid residues (Chanarin et al., 1968). The polyglutamate compound is poorly absorbed by man (Perry and Chanarin, 1968). Much of this polyglutamic folate is deconjugated at the intestinal mucosa into 'free' monoglutamic folate (Streiff, 1969). The 'free' folate is readily absorbed, up to $80 \%$ in fasting subjects (Chanarin et al., 1968).

Streiff (1969) gave a physiological dose of polyglutamic folate by mouth to two groups of women. Serum folate rose significantly less in the women who were taking the contraceptive pill than in the control group. When 'free' folate was given no significant difference in the rise of serum folate was noted between these two groups. Similar observations were made by Snyder and Necheles (1969). This effect on polyglutamic folate absorption was ascribed to inhibition of the intestinal conjugase system by the pill.

A similar mechanism appears to operate in the folate deficiency associated with phenytoin medication. Rosenberg et al. (1968) have shown that phenytoin caused inhibition of folate deconjugation in vitro and impaired the absorption of polyglutamic folate in some healthy volunteers, whereas the absorption of 'free' folate was not impaired.

Although our patient thought she ate an adequate diet, a detailed dietary history revealed a gross deficiency of folate intake. Chanarin et al. (1968) found that the average daily 'free' folate content in urban diets was $160 \mu \mathrm{g}$. Thus even if the pill could have completely blocked the deconjugation of polyglutamic folate, no folate deficiency should have resulted in a woman who ate a balanced diet.

In our patient the combined effects of dietary folate deficiency and enzymatic blockage of folate deconjugation by the pill were sufficient to cause gradual folate depletion and anaemia. When she ate hospital food her increased folate intake induced a rise in haemoglobin despite the continuation of the contraceptive pill. A similar observation was made by Streiff (1969).

We felt that we could not rely on the patient to change her diet. Therefore, we did not feel justified in withholding folate supplement after she stopped taking the pill, merely to confirm the role of the contraceptive pill in inducing her folate deficiency.

Many young women now start a family after taking the pill for some years. An insidious depletion of folate may thus have taken place, especially if dietary intake has been inadequate. This mechanism may be an additional cause of anaemia in early pregnancy.

\section{Acknowledgment}

We wish to thank Dr Fowle, F.R.C.P., for his helpful comments.

\section{References}

Chanarin, I., Rothman, D., Perry, J. \& Stratfall, D. (1968) Normal dietary folate, iron and protein intake with particular reference to pregnancy. British Medical Journaß 2, 394.

DRILL, V.A. (1965) Endrocrine properties and long term safety of oral contraceptives. Metabolism, 14, 295.

Herbert, V. (1962) Minimal daily adult folate requirement: Archives of Internal Medicine, 110, 649.

PerRy, J. \& Chanarin, I. (1968) Absorption and utilization of polyglutamyl forms of folate in man. British Medical Journal, 4, 546.

Rosenberg, I.H., Goodwin, H.A., Streiff, R.R. \& Castle, W.B. (1968) Impairment of intestinal deconjugation of dietary folate. Lancet, ii, 530.

Shojania, A.M., Hornady, G. \& Barnes, P.H. (1968) Oral contraceptions and serum folate level. Lancet, i, 1376.

SNYDER, L.M. \& NeCHELES, T.F. (1969) Malabsorption of folate polyglutamates associated with oral contraceptive therapy. Clinical Research, 17, 602.

STREIFF, R.R. (1969) Malabsorption of polyglutamic folic acid secondary to oral contraceptives. Clinical Research, $17,345$.

STREIFF R.R. (1970) Folate deficiency and oral contraceptives. Journal of the American Medical Association, 214, 105. 